\title{
PROPER ZONATION - AN ESSENTIAL TOOL FOR THE FUTURE CONSERVATION OF THE ŠUMAVA NATIONAL PARK
}

\author{
ZDENKA KřENOVÁ ${ }^{1, *}$ and JAKUB HRUŠKA ${ }^{2}$ \\ ${ }^{1}$ Global Change Research Centre AS CR, v.v.i., Department of Biodiversity Research, Na Sádkách 7, 37005 České Budějovice, \\ Czech Republic; Faculty of Science, University of South Bohemia, Branišovská 31, 37005 České Budějovice, Czech Republic \\ ${ }^{2}$ Czech Geological Survey, Geologická 6, 15200 Praha 5, Czech Republic; Global Change Research Centre AS CR, v.vi.., Bělidla 986/4a, \\ 60300 Brno, Czech Republic \\ *Corresponding author: krenova.z@czechglobe.cz
}

\section{ABSTRACT}

The future of the Šumava National Park is linked to discussions on its zoning. There are two basic approaches to defining national park (NP) zonation: (1) Many European NPs apply a simple concept with a large core area without direct human intervention, which is surrounded by a buffer zone. (2) The second, more ecosystem approach, uses nature values for defining the NP core zones and the level of human intervention is not defined so strictly. This concept is now enshrined in Czech legislation and commonly applied in our national parks. The history of Šumava NP zonation is complex and messy and the current status has been evaluated as unsatisfactory for many years. Since 2004 a new zoning has been under preparation and several different methods generate similar zonation proposals, which shows that the most valuable parts of the Šumava NP have not changed. This article presents a professionally prepared proposal that clearly defines the criteria for defining the conservation zones. Below are descriptions of the major components of the proposed parts of Zone I the most valuable parts of the NP. Justifications for their protection are included.

Keywords: zonation, management of national park, transboundary protected area, Natura 2000, Ramsar site

\section{Introduction}

The Bohemian Forest, with its two national parks, the Sumava NP in the Czech Republic and the Bavarian Forest NP in Germany, forms a unique protected forested area in Central Europe and one of the largest forested areas between the Atlantic Ocean and the Ural Mts. The most valuable parts of the Bohemian Forest, i.e. the highest mountain ranges and mountain plateaus with peat bogs, were included in the Iron Curtain corridor along the Czech-German and Czech-Austrian borders during the second half of the 20th century. A specific military regime strictly protected this area from most human interventions and disturbances. This history and large size of the Bohemian Forest allowed the survival of local natural ecosystems, which took thousands of years to develop. Nowadays, mountain spruce and mixed forests of different ages, together with peat bogs and mountain meadows create a unique mosaic of biotopes, rich in rare, endemic and endangered species like lynx, lutra, pearl mussel, capercaillie, owls, woodpeckers and hole-nesting songbirds, and the same holds for the typical glacial relics that live in the peat bogs.

The Šumava National Park (68,000 ha), established in 1991 to protect the most valuable parts of the Czech side of the Bohemian Forest, forms, together with the neighbouring Bavarian Forest NP, the largest natural wilderness area in the Central-European cultural landscape. Therefore, the first transboundary Central European Wilderness Area of international importance Europe's Wild Heart, was established here in 2008 (Mayer et al. 2009, Křenová and Kiener 2011). The Šumava NP was included in the list of World Biosphere Reserves in 1990 and Šmava peat bogs are an important Ramsar site. The whole region of the Šumava NP is the Natura 2000 protected area, both in terms of the SPA (the Bird EU Directive) and SAC (the Habitat EU Directive).

Long-time debates on the future of nature conservation in the Bohemian Forest are linked with discussions on zoning of the Šumava NP. Unfortunately the fact that zoning is not a goal but a very important tool of conservation is currently not included in these discussions. There are two basic approaches to defining NP zonation (Brunner 1996; Dudley 2008).

A simple concept of a large core area without direct human intervention, in which natural processes are allowed and welcome, is applied in many European NPs. The natural core area is usually surrounded by a buffer zone that separates the core from the neighbouring landscape. This concept is applied for example in the Triglav National Park, Slovenia (Solar 2009) and Bavarian Forest National Park, Germany (Kiener et al. 2008).

The second, more ecosystem approach, uses nature values as a main key for defining NP core zones. Level of human intervention and appropriate management practices are not defined so strictly. This concept is now enshrined in Czech legislation and commonly applied in our national parks.

\section{The first and second zonation of Šumava NP}

The Article 4 of the Czech Government Regulation No. 163/1991 of March 20, 1991, which established the Šumava NP and set the conditions for its protection, says: 
Table 1 Changes in the zoning of the Šumava NP from 1991-2011. The current zonation system, which is still valid, is in bold. A proposal put forward in 2004 has not been validated.

A new zonation proposed in 2011 respects the slight shifts in habitat quality that occurred between 2005 and 2010, especially the effect of the gales in January 2007. Results of previous negotiations are also included.

\begin{tabular}{|l|c|c|c|c|c|c|}
\hline & Zone I & & Zone II & & Zone III & \\
\hline & Area [ha] & \% of total NP area & Area [ha] & \% of total NP area & Area [ha] & \% of total NP area \\
\hline 1991 & 15,195 & 22 & 51,845 & 75 & 1,989 & 3 \\
\hline $\mathbf{1 9 9 5}$ & $\mathbf{8 , 0 7 0}$ & $\mathbf{1 3}$ & $\mathbf{5 5 , 8 8 5}$ & $\mathbf{8 2}$ & $\mathbf{3 , 3 7 2}$ & $\mathbf{5}$ \\
\hline 2004 (proposal) & 26,550 & 39 & 40,640 & 57 & 2,693 & 4 \\
\hline 2011 (proposal) & & \multicolumn{5}{|c|}{ similar to 2004 } \\
\hline
\end{tabular}

(1)Methods and ways of protecting the national park are differentiated according to the distribution of the national park into three zones defined according to the natural values.

(2) Areas with the most important natural values in the national park are classified as Zone I (strictly natural), particularly natural or slightly amended ecosystems. The aim is to preserve or restore natural ecosystem processes and limit human intervention into the natural environment to maintain this state.

Since the establishment of the Šumava NP its zonation has undergone significant changes (see Table 1, Fig. 1). At the beginning Šumava NP zonation mostly accepted the international concept of zoning as a basic tool for scaling the value and protection of the NP interior. Fifty-four units of Zone I included a mosaic of habitats and island occurrences of mires, habitats of the highest value, often surrounded by forests historically partly affected by forestry. Most of the best places, including natural reserves protected long before the establishment of the Šumava NP (i.e. Modravské slatě, Chalupská slat', Jezerní slat, Trojmezná) were included in Zone I. Many of them were managed without direct human intervention for decades.
In 1995 there was a change in the leadership of the national park, which brought about a change in the concept of NP management. The size of Zone I was reduced and the original 54 units were further fragmented into 135 smaller units. The main reason was a strong desire for active management, mainly the logging of bark beetleinfested trees. The new definition of Zone I was based primarily on forest typology and this zone included large peat bogs and old forest fragments, which were supposed to be ecologically stable and highly resistant to natural disturbances (primarily bark beetles infestation). Most of the units of Zone I were too small for natural processes and also many valuable habitats, particularly smaller raised bogs and waterlogged spruce forests, were excluded from Zone I and transferred to Zone II, where standard forestry practices were applied. Non-intervention management agreement formerly applied in fragmented Zone I was already broken in 1998. The main argument for this was the necessity to prevent the spread of bark beetles to forests in Zone II. Cutting of bark beetle-infected tress and cleaning of up-rooted trees were allowed in many units of Zone I. This was strongly criticized by experts, representatives from NGOs and international organizations (IUCN, Ramsar Committee). One of the main
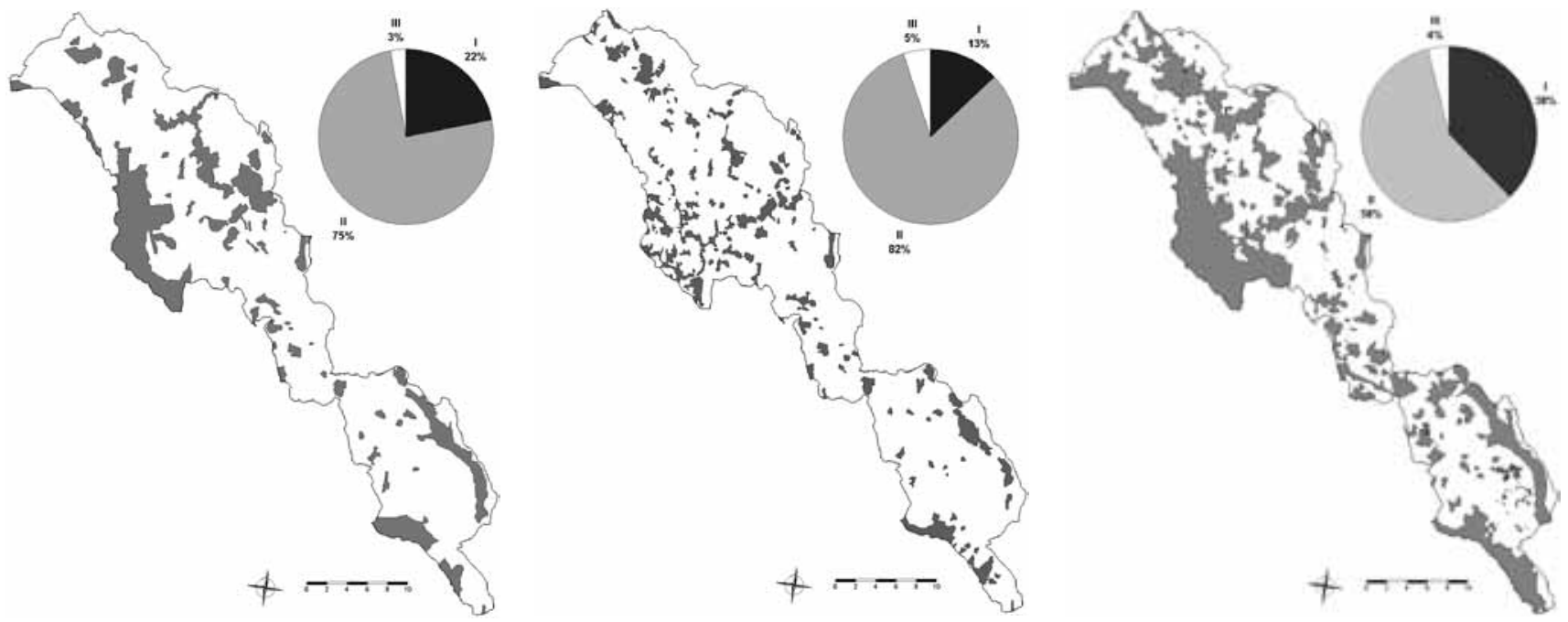

Fig. 1 The size and fragmentation of Zone I (strictly protected) of the Šumava NP in the years 1991 (Fig. 1A), 1995 (Fig. 1B) and 2004 (Fig. 1C). Also the percentage of the total area in Zone I (black), Zone II (shadow), and Zone III (white) are showed. 
recommendations of the IUCN expert mission in 2002 was "to simplify and harmonize zoning (National Park zonation, silent zone, pedestrian zone of the Biosphere Reserve and Ramsar area) into one single system of different modes. In particular, current fragmented zonation and different management regimes should be simplified and the core zone of a few larger units with non-intervention management, surrounded by a buffer zone should be distinguished."

\section{A new zonation proposal}

In spring 2004, the Czech Minister of Environment ordered the preparation of a new zonation following the international experts' recommendations. The new proposal included the extension of Zone I to 39\% of the Sumava NP area with the main goals of respecting natural conditions, minimizing the negative effects associated with the fragmentation of zoning and above all respect the current legislation. More than half of this area, $20 \%$ of the NP, was proposed as the core zone without direct human intervention. Unfortunately, negotiations with local communities and politicians were not successful and the new zonation has not yet been officially approved despite several modified versions of the new zonation having been prepared and discussed at round table and public meetings. The main obstacles were the management of bark beetles, regulation of public access to the core zone and plans for various developments in different parts of the NP.

\section{A new Šumava National Park Act}

During the last couple of years the calls of politicians to have a Law for the Sumava NP have escalated and the Ministry of Environment intensified its preparation. A new zonation was seen to be an important part of the Law proposal was prepared with a desire to achieve a reasonable consensus. A new NP zonation, similar to that used in other internationally recognized national parks, could be a good tool for achieving a long-term concept for the Šumava NP. It should be based on large units with good potential for self-development. A broad spectrum of experts who have studied ecosystems in the Bohemian Forest for a long time participated in this project. It is the joint work of specialists from the Sumava NP Headquarters, members of the Scientific Section of the National Park Council (later Shadow Scientific Council of the National Park) and members of the scientific panel assembled by the Ministry of Environment. The proposal was compiled based on principles that have already been used in a prepared Šumava NP Management Plan from 2010, which unfortunately was never included in the negotiation process.

This proposal takes into account the current condition of the Šumava ecosystems, as well as the latest knowledge and experience of the dynamics of these ecosystems, the effects of natural disturbances, knowledge of population dynamics and ecological requirements of flagship species.
The new zoning proposal also respects the recommendations of international arbiters of nature, among other things, published recommendations regarding the award of the prestigious Council of Europe Diploma Šumava National Park published in 2011. They concluded that the existing zoning system was unsatisfactory and recommended that we discuss and adopt documents that aim to remedy the situation, namely: a new management plan, zoning and management guidelines for different zones of the Šumava NP no later than 2012. The proposal was submitted to the Ministry of the Environment, which should be the basis for the expert group meetings preparatory to producing the Law on the National Park Šumava.

The new zonation proposal is based on the following assumptions:

Zone I includes the area with a high concentration of natural values and represents the most valuable parts of the national park. These are primarily habitats that cover large areas and are little affected by human influences. In addition, there are several smaller areas, which include extremely valuable habitats, which complement those in the larger units.

The main aim of defining Zone $\mathrm{I}$ is to protect the extremely valuable natural areas in which spontaneous processes take place without direct human intervention, and protect the primary biodiversity (i.e., the natural biodiversity). Therefore, the predominant part of Zone I is to be left to develop spontaneously and includes ecosystems for which the optimal management is non-intervention. Most of them are natural ecosystems with no or little history of human intervention and ecosystems in various stages of succession, which lead to long-term natural state. Large areas of wild nature are located mainly in the central part of the Šumava NP and largely linked to similar communities in the neighbouring Bavarian Forest National Park. This area is the Wild Heart of Europe (Křenová and Kiener 2011). No management activities are planned in this area and only single or limited targeted measures to promote natural processes in ecosystems (e.g. restoration of water regime in peat bogs or removing old roads) are contemplated. Also breeding areas of key species (e.g. black grouse) which also require temporary or occasional management are included in Zone I.

The extremely important sites of secondary (the human contingent) biodiversity are also included in Zone I. Especially valuable non-forest habitats (species rich mountain grasslands) and locations where there are very rare species are included but their area only makes up 5\% of the total area of Zone I. The total area of forest in Zone I is 18,233 ha and of deforested areas $1,202 \mathrm{ha}$, which together make up $28.4 \%$ of the area of the Šumava NP.

Zone II includes the natural areas that in the past were variously influenced by human activities, which now generally require active management. Differently applied active management measures, either on a temporary basis or permanently, are therefore planned in Zone II. Different 
treatments carried out in forests of Zone II are intended to prepare part of the territory (Zone IIa) for inclusion in Zone I in the medium or long term (up to a maximum of 30 years). The total area of the proposed Zone IIa is 7,321 ha ( $10.7 \%$ of the Šumava NP). In the rest of Zone II continuous active management (sustainable environmental-friendly forestry and farming) is planned. Zone II is both a buffer zone for the national park and community background.

Zone III includes urban villages and adjacent nonforest area, where the main habitats are heavily modified and altered by human activities. The core area of Zone III contains built-up areas and areas that have the potential to become built-up within the meaning of the Act No. 183/2006 Coll. Planning and Building Regulations. Zone III is intended for the development of municipalities; however it does not automatically mean that the whole area is a built-up area and other landscape functions should be incorporated in urban plans. In some cases there are very valuable plant communities (peat meadow, rich flowery mountain meadows, heaths) requiring friendly methods of treatment which, due to fragmentation of the zoning have to be included.

The new zoning proposal assumes that public access will be restricted to designated trails only in parts of Zone I, such as locations where there are fragile habitats (e.g., peat bogs) and areas where there are animals susceptible to disturbance (e.g., grouse, black grouse, peregrine falcon).

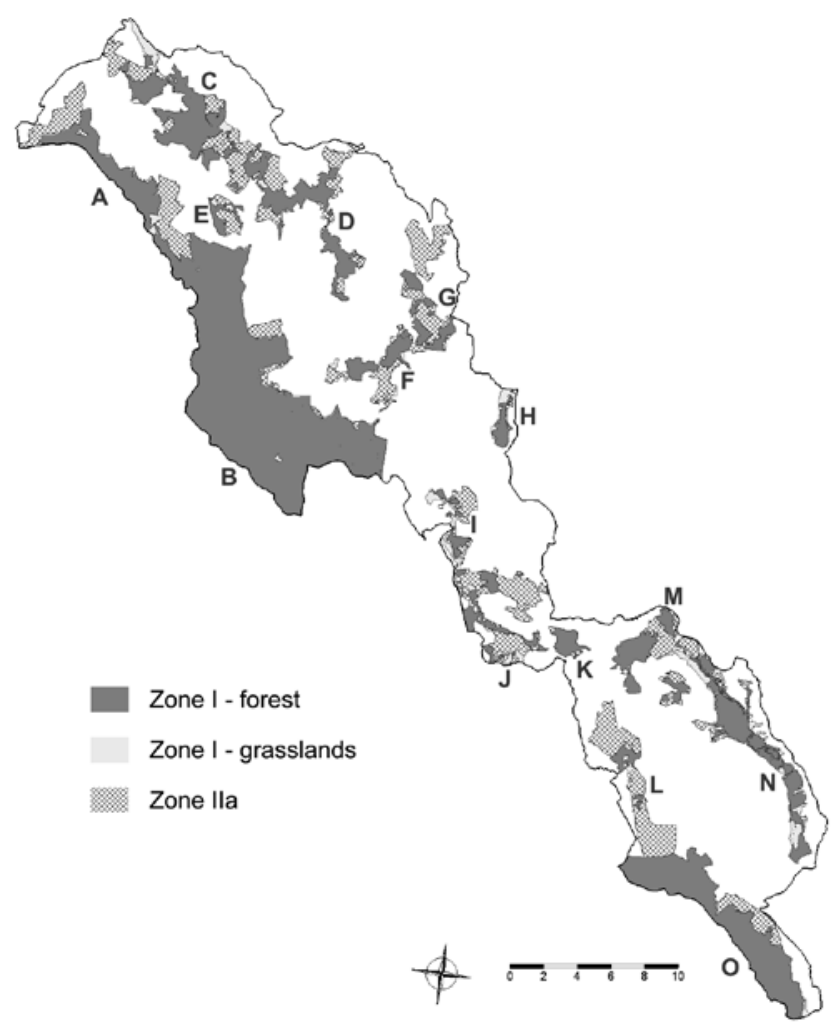

Fig. 2 A proposal of new zonation of Šumava NP. The Zone I (strictly protected; forest $=18,233 \mathrm{ha}$, grasslands =1,202 ha) and Zone Ila (forest $=321 \mathrm{ha}$ ), where different treatments are planned to prepare part of the territory for inclusion in Zone I in the medium or long term (up to a maximum of 30 years), are showed.

\section{Description of the main parts of Zone I}

The proposed Zone I has fifteen parts (Fig. 2) some of which are planned to be connected to bigger units during the next 30 years when Zone IIa is incorporated in Zone I.

\section{Part A: Debrník - Plesná - Poledník (Debrník Valley - Plesná Mt. - Poledník Mt.)}

Location: A large area located along the state Czech German border north-west of Poledník Mt. (1315 m a.s.l.). This area is mountainous with several notable peaks (Poledník, Předěl, Ždánidla, Plesná and Polom) and the Debrník Valley. This area is directly connected with a large part of Zone I, "Modravské slatě", in the cetral part of the Šmava NP.

Conservation objectives: Mountain acidophilous beech forests; species rich beech forests; mountain spruce forests; waterlogged peat and spruce forests; glacial lakes; capercaillie, lynx.

Natural characteristics: This mountain range forms the northwest border of the Upper Šumava Plains. There are several glacial cirques and two with glacial lakes (Prášilské, Laka). Stará Jímka (Old Well) was also a shallow glacial lake but is now full of natural sediments. The slopes of the glacial cirques are less pronounced and covered with forest and lack the typical rocky amphitheaters and subalpine vegetation. The altitudinal gradient is considerable ranging from several mountain peaks above $1200 \mathrm{~m}$ a.s.l. to deep valleys. Temperature inversions in some deep valleys affect the vegetation but the main type of zonal vegetation in this area are acidophylous beech forests (all. Luzulo-Fagion). Mountain spruce forests (all. Piceion excelsae) occur naturally only at the highest altitudes above $1200 \mathrm{~m}$. Large wind-blow areas after the Kyrill hurricane that swept the mountains in January 2007 were left without intervention on the highest parts of Plesná, Ždánidla and Polom peaks. These areas offer a unique opportunity to study post-disturbance natural regeneration of mountain forets.

Azonal forest vegetation represented by different types of peat and waterlogged spruce forests (as. Bazzanio Piceetum, Sphagno-Piceetum) occurs in the territory only locally, mostly in valleys, or in shallow depressions near springs or mountain saddles. Other types of peatlands are represented by the small-scale minerotrophic transition mires (all. Sphagno-Caricion canescentis) with dominant species Carex rostrata, C. nigra and Eriophorum angustifolium. Typical ombrotrophic bogs are nearly missing. Different types of ombrotrophic peat bogs (all. Caricion canescenti-nigrae) occur also in historically deforested enclaves and grasslands. Nardus stricta meadows together with species poor grasslands (all. Violion caninae) are typical locally for poor shallow soils. Young succession stages cover some parts of the former iron curtain corridor. 
Fauna typical of beech forests live here. Macrogastra badia and Petasina edentula, the alpine elements, are interesting representatives of molluscs. The black stork (Ciconia nigra), stock pigeon (Columba oenas), capercaillie (Tetrao urogallus), hasel grouse (Bonasa bonasia), white-backed woodpecker (Dendrocopos leucotos), redbreasted flycatcher (Ficedula parva) and lynx (Lynx lynx) regularly breed in this area. The important boreomontane faunal elements occur at the highest altitudes.

\section{Part B: Modravskéslatě (Modrava moors)}

Location: This large area includes the central part of the Upper Šumava Plains along the Czech-German border, spring of the Vltava River, Kvilda and Modrava villages. A series of several important peat bogs (Rybárenské slatě, Cikánské slatě, Ztracená slat', Ptačí nádrž and Černohorský močál) together with surrounding waterlogged forests define the northern boundary of this area. This part of Zone I is connected to Part A near Poledník Mt.

Conservation objectives: The complex of bogs (peat and waterlogged spruce forests, bogs, transition mires, fens); mountain spruce and acidophilous beech forests, mountain Nardus meadows and heathlands; capercaillie, relict fauna of natural habitats. This is an extremely valuable and compact area, which together with the neighbouring natural zone of the Bavarian Forest NP forms the largest island of natural habitats in the middle of the Central European cultural landscape.

Natural characteristics: Modrava moors are located at the center of the Bohemian Forest and covers a substantial part of the Upper Šumava Plains. This plateau is characterized by a slightly undulating surface at an altitude of about $1100 \mathrm{~m}$ a.s.l. with rounded peaks reaching $1300 \mathrm{~m}$ a.s.l. The bedrock consists mainly of gneisses, which are locally permeated by granitoid rocks. Numerous geomorphological and paleopedological phenomena (caroids, cryoplain terraces, soils graded by frost, solifluction sediments, debris, etc.) indicate the periglacial climatic history of this area.

Mountain spruce forests (all. Piceion excelsae) are the predominant type of forest in this area. Slopes and damper positions are populated by communities of all. Piceion Athyrio-alpestris. Widely represented are azonal forest communities and waterlogged peat spruce forests (as. Sphagno Piceetum and Bazzanio-Piceetum), which sometimes are quite extensive in shallow valleys and depressions in the terrain around bogs. A special type of forest occurs in areas historically used as pastures, the pasture forests. Flat topography, ocean-themed humid local climate and low permeable soils with numerous springs determine the characteristic phenomenon of this area, the peat bogs. They occur in a wide range of types and developmental stages depending on the habitat conditions.

Two main types of mountain ombrotrophic mires can be distinguished: bogs covered by dwarf pines (Pinus $\times$ pseudopumilio) and open mires with dwarf spruce. Typical vegetation of naturally non-forested sites is best developed at still active mires with open water at their center. Bults covered with shrub and dominant bog-bilberry (Vaccinium uliginosum) and flat grasslands with deer grass (Trichophorum caespitosum) are described as (all. Oxycocco microcarpa-Empetrion hermaphroditi and Sphagnion magellanica). Surface depressions and edges of peat lakes are often overgrown by different communities of sedges and peat mosses (usually all. Scheuchzerietalia palustris).

At some springs, especially those at the foot of the main ridge, there are high numbers of alpine elements, for example Senecio subalpinus, Rumex alpestris, Swertia perennis and Aconitum plicatum. Natural non-forest vegetation is represented only in the fragments with peat bogs. Also, secondary grasslands occur only in small areas, mostly along the major watercourses and former grazing areas in forests.

Significant invertebrate faunas occur in the bogs and zonal spruce forests. This area is very important for several endangered vertebrates - capercaillie (Tetrao urogallus), three-toed woodpecker (Picoides tridactylus), ouzel (Turdus torquatus), Tengmalm's owl (Aegolius funereus), pygmy owl (Glaucidium passerinum) and alpine shrew (Sorex alpinus). Lynx is also a permanent resident here.

\section{Part C: Kotlina horní Křemelné (Peat bogs in the upper basin of the Křemelná River)}

Location: This is a flat basin in the upper part of the Křemelná River north of the village Nová Hůrka. The east border is defined by the Křemelná River canyon nearby the former village, Stodůlky.

Conservation objectives: The peat bogs complex (peat and waterlogged spruce frorests, bog pine forests, transition mires, and fens); natural successional areas; mountain acidophilous beech forests; wetland meadows; mountain alders; natural river area; Czech gentian; black grouse.

There are very well-preserved natural forest complexes in this area, especially at waterlogged sites.

Natural characteristics: This area is characterized by a large number of peat bogs of various types, especially common are valley bogs, peaty and waterlogged spruce forests and minerotrophic grassland peat bogs. Peat bogs occur both on the floodplain of the Křemelná river and on gradual slopes. Ombrotrophic peat bogs in valleys (all. Sphagnion magellanici, as. Pino rotundatae-Sphagnetum) are formed mainly by bog pine (Pinus rotundata), with spruce (Picea abies) and birch (Betula pubescens) at the edges. Pine (Pinus sylvestris) is dominant at some bogs.

Peat bogs are surrounded by large water logged spruce forests of as. Sphagno-Piceetum and Bazzanio-Piceetum. In particular, the first appointed ones are the best preserved natural forest ecosystems in the territory. In sever- 
al places, non-forest transition mires of various types (all. Sphagno Caricion canescentis) form a mosaic with water logged peat spruce forests. Various sedges (Carex rostrata, Cx. nigra etc.) and cotton grass (Eriophorum angustifolium) are typical species of minerothophic bogs and peat grasslands (all. Sphagno-Caricion canescentis, Caricion canescenti-nigrae). The species-rich fens with lesser panicled sedge (Carex diandra) are relatively rare in this area. Mountain beech and fir acidophilous forest are the typical vegetation here but some of them were largely previously managed for producing mainly spruce. This area used to be a military training area during the second half of 20 th century. Military activities ceased more than 20 years ago but habitats of the initial succession series still exist here. Many endangered and rare species (i.e. Pedicularis sylvatica, Pinguicula vulgaris, Botrychium matricariifolium, Parnassia palustri and Ophioglossum vulgatum) colonized these areas. Corallorhiza triffida, Dactylorhiza fuchsii, Carex diandra, Montia hallii, Aconitum plicatum, Scorzonera humilis and other species on the Czech Red List occur here.

Relict species of the bog habitats, for example Clubiona norvegica, Gnaphosa microps, Carabus menetriei and Colias palaeno, are typical representatives of the invertebrate fauna in this area. This is also a breeding area for black grouse (Tetrao tetrix), capercaillie (Tetrao urogallus), three-toed woodpecker (Picoides tridactylus), ouzel (Turdus torquatus) and Tengmalm's owl (Aegolius funereus). Otter (Lutra lutra) and lynx (Lynx lynx) are permanent residents here.

\section{Part D: Kaňony Křemelné a Vydry (The Křemelná River and the Vydra River canyons)}

Location: This large area is comprised of the Křemelná River canyon north of Srní and the Vydra River canyon between Antýgl and Čeňkova Pila. The steep west slopes in the valley of the Otava river between Čeňkova Pila and Rejštejn are also included.

Conservation objectives: Relict pine forests; rock fields, cliff habitats; azonal spruce forests at the bottom of the valleys; canyons; mountain alder growths, mountain beech and fir forests; hazel grouse; peregrine falcon; otter; lynx.

Natural characteristics: The area is characterized by rugged topography and sloping terrain with large differences in altitude (over $200 \mathrm{~m}$ ). Bedrock consists mainly of gneisses, biotite granite of weinsber type is common on the eastern slopes of the Vydra river canyon. Periglacial terrain modeling with frost rocky blocks and rock fields are typical phenomena of the steep slopes of canyons. Acidophilous mountain beech and fir forests together with relict pine cover rocky slopes. Azonal spruce and water logged spruce forests occur at the bottoms of canyons. Fragments of relict primeval mixed stands persist in inaccessible locations. Several xerophytic species, for example golden alys- sum (Aurinia saxatilis), oblong woodsia (Woodsia ilvensis), or blasses habichtskraut (Hieracium schmidtii), occur on open rocky outcrops and exposed rocks in canyons. Also xerophytic oregano (Origanum vulgare) and narrowleaved everlasting pea (Lathyrus sylvaticus) occur in the Otava river valley. Mountain alder stands (all. Alnion incanae) are well represented on narrow floodplains of rivers and along small tributaries. Specific microcavernic fauna live in boulder screes. Rare spiders Bathyphantes simillimus and Diplocentria bidentata or galley worm Leptoiulus montivagus are examples of Nordic and darkness tolerant relicts. Also the rare mollusc Bulgarica cana occurs here. Significant is the occurrence of hazel grouse (Bonasa bonasia), otter (Lutra lutra) and lynx (Lynx lynx).

\section{Part E: Velký Bor - Slunečná (Area around former villages Velký Bor and Slunečná)}

Location: Mainly grasslands in different stages of succession located in the flat valley of the Jezerní potok south of the road from Srní to Prášily.

Conservation objectives: Natural successional areas, water logged and peat spruce forests, transition mires, moss fens, wetland grasslands; spring meadows; hazel grouse; panonic gentian.

Natural characteristics: Most of the historically deforested areas is currently subject to spontaneous succession. The wet habitats often become small-scale minerotrophic peat bogs (usually all. Caricion canescenti-nigrae) and meadow wetlands (all. Calthion palustris). Different early successional stands of abandoned meadows. Peat birch stands and willows are dominant in wet habitats and mixed birch and pine stands colonize mesophitic areas. Northern and eastern edges of the area are water logged and covered by peat spruce forests (Sphagno-Piceetum, Bazzanio-Piceetum). Also in this area there are several small-scale transition mires (all. Sphagno-Caricion canescentis), bog pine forests and springs. Acidophilous mountain mixed forests grow in southeastern part of this area.

Yellow coral root (Corallorhiza trifida), common Lousewort (Pedicularis sylvatica), common butterwort (Pinguicula vulgaris), Hangurian gentian (Gentiana pannonica), grass of Parnassus (Parnassia palustris), common sundew (Drosera rotundifolia), common cranberry (Oxycoccus palustris), bog rosemary (Andromeda polifolia), mountain arnica (Arnica montana) and several other endangered and rare plant species occur here. Hazel grouse (Bonasa bonasia) and lynx (Lynx lynx) are the most important vertebrates in this area.

\section{Part F: Tetřevská slat', Jezerní slat', Rašeliniště pod Tetřevem (Mires: Tetřevská slat,' Jezerní slat,' Rašeliniště pod Tetřevem)}

Location: A large area around the Kvilda, Horská Kvilda and Filipova Hut villages in the central part of the Šumava Mountains. 
Conservation objectives: The complex of peat bogs (peat and water logged spruce forests, transition mires and fens); montane spruce forests; capercailie; black grouse.

Natural characteristics: This area is a part of the Upper Šumava Plains and includes large wetlands in the catchments of the Jezerní potok and Filipohut'ský streams. Terrain is a gently undulating plateau in a flat mountain saddle at an altitude of about 1050-1140 m a.s.l. Spruce bog forests and transition bogs are among the best preserved natural habitats in this area.

Several ombrotrophic mires with a cover of Pinus $\times$ pseudopumilio are surrounded by large peat and water logged spruce forests (Sphagno-Piceetum, Bazzanio-Piceetum). Tetřevská slat' is still active with open water in the center and typical shrub communities (all. Sphagnion magellanici), grassland with Trichophorum caespitosum and a low lying area with different sedges (all. Sphagnion cuspidati). An important part of Jezerní slat mire was degraded by peat cutting. Secondary vegetation, heathland with bog blueberry (Vaccinium uliginosum), heather (Calluna vulgaris), crowberry (Empetrum nigrum) and tussock cottongrass (Eriophorum vaginatum) have colonized the depressions at this site. The untouched part of this mire is characterized by open water with shrubs and a large peat lake with mud sedge (Carex limosa). Transition mires (all. Sphagno-Caricion canescentis), mostly dominanted by bottle sedge (Carex rostrata), common sedge (C. nigra) and common cotton grass (Eriophorum angustifolium) are common in this area. Large open transition mires with many springs (locally with Montia hallii) cover the gentle slopes above Jezerní slat' mire.

Mud sedge (Carex limosa), few flower sedge ( $C$. pauciflora), bog sedge (C. paupercula), Rannoch-rush (Scheuchzeria palustris), deer grass (Trichophorum cespitosum), crowberry (Empetrum nigrum), bog rosemarry (Andromeda polifolia), cranberry (Oxycoccus palustris), common sundew (Drosera rotundifolia), heart-leaved tway blade (Listera cordata), dwarf birch (Betula nana), and several other endangered species are common in this area.

Various invertebrates typical of peat bogs occur in this territory: for example the spiders Arctosa alpigena lamperti and Pardosa hyperborea, aphids Calaphis arctica and Symydobius nanae, butterflies Boloria aquilonaris and Vacciniina optilete, carabid Trechus alpicola, dragonflies and several rare and relict Diptera. Capercaillie (Tetrao urogallus), black grouse (Tetrao tetrix), three-toed woodpecker (Picoides tridactylus), Tengmalm's owl (Aegolius funereus), Pygmy owl (Glaucidium passerinum) and ring ouzel (Turdus torquatus) are typical vertebrates of this area.

\section{Part G: Horskokvildské slatě and Mezilesní slat' (Mires: Horskokvildské slatě and Mezilesní slat)}

Location: A flat forested area in the center of the Upper Sumava Plains on which there is a complex of peat bogs and water logged forests located about $1 \mathrm{~km}$ north- east of Horská Kvilda and springs in the area of the Hamerský potok and Losenice creeks.

Conservation objectives: The complex of peat bogs (peat and water logged spruce forests; peat bogs; transition mires and fens); montane spruce forests; acidophilous beech forests; capercaillie; black grouse; hazel grouse.

Natural characteristics: Peat and water logged spruce forests (Sphagno-Piceetum, Bazzanio-Piceetum) and moors covered by stands of Pinus $\times$ pseudopumilio. Zonal vegetation is described as montane spruce forests and acidophilous beech forests. Secondary heathland communities, with bog blueberry (Vaccinium uliginosum) and heather (Calluna vulgaris), occur in some areas where peat was cut in the past (i.e., Zhưřská slat'). Tussock cotton grass (Eriophorum vaginatum) and different sedges (all. Sphagno-Caricion canescentis a Caricion canescentinigrae) occur in the depressions.

Transition mires (all. Sphagno-Caricion canescentis) with bottle sedge (Carex rostrata) are rare in this area and the small forest meadows are species-poor. Some montane Nardus meadows, Natura 2000 priority habitat, and peat meadows (all. Caricion canescenti-nigrae) occur in the southern part of this area.

Several endangered species including bog rosemary (Andromeda polifolia), cranberry (Oxycoccus palustris), common sundew (Drosera rotundifolia), crowberry (Empetrum nigrum), monk's hood (Aconitum plicatum), mountain arnica (Arnica montana), snowbell (Soldanella montana) and stiff clubmoss (Lycopodium annotinum) are more or less common here. Several species of relict invertebrates live in this area. Olophrum transversicolle (Staphylinidae) is probably the most unique example because currently it is only known from the Šumava Mts., Alps and Altai Mts. All three species of grouse, capercaillie (Tetrao urogallus), black grouse (Tetrao tetrix) and hazel grouse (Bonasa bonasia), are regularly breeding in this area. Also three-toed woodpecker (Picoides tridactylus), Tengmalm's owl (Aegolius funereus), Pygmy owl (Glaucidium passerinum), and ring ouzel (Turdus torquatus) are living there.

\section{Part H: Chalupská slat' (Chalupská slat'mire)}

Location: Wetlands in the valley of the Vydrí potok creek, north of village Borová Lada.

Conservation objectives: The complex of peat bogs (peat and water logged spruce forests; peat bogs; peat birch stands; transition mires and fens); natural succession; wet grasslands; montane Nardus meadows; back grouse; Trichophorum alpinum; Carex dioica.

Natural characteristics: The wetlands in the valley of Vydří potok creek are covered by a mosiac of azonal vegetation, primarily by peat bogs, peat and waterlogged spruce forests and alder stands. This area was strongly 
affected by human activities in the past (mainly deforestation and peat cutting), which changed the vegetation cover over a large area and resulted in the current mosaic of peat bogs, wetland meadows and mountain grasslands. Some of these secondary habitats were abandoned during the 20th century and currently are in different stages of succession.

The best preserved and the largest peat bog in the area is Chalupská slat' moor with its central lake. Floating peat islands host rare plant communities (all. Sphagnion cuspidati). Although more than half of this moor was affected by cutting peat by hand in the past, the area as a whole has regenerated relatively well. Sedges (all. Sphagno-Caricion canescentis) are dominant in the deeper post-cutting depressions with a good water supply. Vegetation of all. Sphagno warnstorfi-Tomentypnion nitentis with several endangered species (i.e., Trichophorum alpinum or Carex dioica) rarely colonizes post-cutting depressions. The relict invertebrate fauna is represented by spiders, Gnaphosa microps and Pardosa hyperborea, butterflies Boloria aquilonaris and Vacciniina optilete, and a leaf beetle Chrysomela lapponica. This part of the Bohemian Forest is also one of the westernmost mountain habitats of the northern birch mouse (Sicista betulina) and breeding area of black grouse (Tetrao tetrix).

\section{Part I: Knižecí Pláně - Buková slat' (Mountain meadows around former village Knižecí Pláně and Buková slat'mires)}

Location: Southeastern part of the Šumava Plains, about $4 \mathrm{~km}$ southwest of Borová Lada.

Conservation objectives: The complex of peat bogs (peat and water logged spruce forests; peat bogs; peat birch stands; transition mires and moss fens); natural succession; wet grasslands; mesophytic meadows, montane Nardus meadows; back grouse; corn crake.

Buková slat' mire is one of the oldest nature reserves in the area (protected since 1933).

Natural characteristics: Mostly non-forest enclave with several ombrotrophic mires. Bogs in advanced stages of succession are covered with Pinus $\times$ pseudopumilio stands. Vegetation of the all. Sphagnion magellanici grows at the edges of the open moors. Reeds (Phragmites australis) are locally present. Non-forest vegetation in open areas is composed mainly of a mosaic of peat grasslands dominated by Carex nigra (all. Caricion canescenti nigrae) and a few species rich communities with Willemetia stipitata. There are also transition mires and springs (all. Swertio perennis-Dichodontion palustris) in this area. Peat bogs are surrounded by peat and water logged spruce forests (Sphagno-Piceetum, Bazzanio-Piceetum).

Many rare and endangered plant species occur in this area, for example: bog rosemary (Andromeda polifolia), cranberry (Oxycoccus palustris), deer grass (Trichophorum cespitosum), marsh lousewort (Pedicularis palustris), common lousewort (Pedicularis sylvatica), buckbean
(Menyanthes trifoliata), common sundew (Drosera rotundifolia), heart-leaved tway blade (Listera cordata), marsh club moss (Lycopodiella inundata), monk's hood (Aconitum plicatum) and Doronicum austriacum.

Relict fauna is represented for example by several butterflies: Proclossiana eunomia, Boloria aquilonaris and Colias palaeno. Common lizard (Zootoca vivipara) is common in this area and black grouse (Tetrao tetrix), capercaillie (Tetrao urogallus) and corn crake (Crex crex) regurarly breed in this area.

\section{Part J: Ždárecké slatě - Řasnice (Žd’árecké slatě mires - valley of the Řasnice River)}

Location: This is a large area in the southern part of the Šumava NP along the Czech - German state border, southwest of Strážný. Areas with springs in the Červený potok creek (the Danube River catchment) and Řasnice (the Vltava River catchment) are included.

Conservation objectives: The complex of peat bogs (peat and water logged spruce forests; peat bogs; peat birch stands; transition mires and moss fens); natural succession; grassland wetlands; montane Nardus meadows; black grouse; capercaillie; corn crake.

Natural characteristics: Large parts of this area were colonized and deforested in the past. It includes several ombrotrophic mires. Bogs in the advanced stages of succession are covered with stands of Pinus $\times$ pseudopumilio. From the forestry point of view, especially well preserved pine bogs with stands of birch or spruce on peat are the most valuable. Vegetation of the all. Sphagnion magellanica is maintained in the central part of Ždárecká slat mire and at the edges of several other moors in this area. Non-forest vegetation is composed mainly of a mosaic of peat grasslands dominated by Carex nigra (all. Caricion canescenti nigrae) and a few species rich communities with Willemetia stipitata.

Cranberry (Oxycoccus palustris), bog rosemary (Andromeda polifolia), deer grass (Trichophorum cespitosum), common lousewort (Pedicularis sylvatica), buckbean (Menyanthes trifoliata), common sundew (Drosera rotundifolia), heart-leaved tway blade (Listera cordata), marsh club moss (Lycopodiella inundata), monk's hood (Aconitum plicatum) and several other rare plant species grow here. Relict invertebrates typical of peat bogs occur here: i.e., butterflies Proclossiana eunomia, Boloria aquilonaris, Vacciniina optilete and Colias palaeno; carabid Carabus menetriesi. This is also an important breeding area for capercaillie (Tetrao urogallus).

\section{Part K: Stráženská slat'(Stráženská slat'moors)}

Location: An isolated bog located about $500 \mathrm{~m}$ southeast of Strážný.

Conservation objectives: The complex of peat bogs (peat and water logged spruce forests; peat bogs; peat 
birch stands; transition mires and moss fens); natural succession; wet grasslands; mountane mesophytic meadows; black grouse; corn crake.

Natural characteristics: The large ombrotrophic peat bog is covered by a stand of Pinus $\times$ pseudopumilio in the central part and a stand of dwarf Pinus rotundata at the edges. Peat shrub communities (all. Sphagnion magellanici) are abundant. Carex paupercula and Scheuchzeria palustris (all. Sphagnion cuspidati) are dominant in small depressions and peat lakes. Smaller fragments of pine peat forests and water logged spruce forests were maintained on the northern part of this peat bog. Different successional stages and self-seeded trees are locally common. Grasslands surrounding the peat bog are composed of a mosaic of minerotrophic peat meadows (all. Caricion canescentinigrae) and wet meadows (all. Calthion palustris) usually dominated by Deschampsia caespitosa or Carex brizoides.

Monk's hood (Aconitum plicatum), cranberry (Oxycoccus palustris), bog rosemary (Andromeda polifolia), common sundew (Drosera rotundifolia), dwarf birch (Betula nana) and several other endangered species are common in this area. Typical representatives of relict invertebrates are for example the spider Pardosa sphagnicola and butterflies Vacciniina optilete, Colias palaeno, Proclossiana eunomia, Boloria aquilonaris and Erebia euryale. This is also a breeding area for black grouse (Tetrao tetrix) and corn crake (Crex crex).

\section{Part L: Spálený luh (Spálený luh floodplain wetlands)}

Location: About $1.5 \mathrm{~km}$ south of České Žleby, near the crossing point Nové Údolí on the Czech-German state border.

Conservation objectives: The complex of peat bogs (moors, transition mires; peat and water logged spruce forests; peat birch stands; fens); natural succession; corn crake; an important migration corridor.

Natural characteristics: A complex of ombrotrophic moors and peat, and water logged spruce forests (Sphagno-Piceetum, Bazzanio-Piceetum) situated on southeastern slope of the hill called Kaprad' (1026 m a.s.l.). There are also fragments of transition mires and secondary peat birch stands here.

It is an important area for relict invertebrates living in peat bogs. For example, the spider Pardosa sphagnicola and butterflies Proclossiana eunomia, Boloria aquilonaris, Vacciniina optilete, Colias palaeno, and Erebia euryale regularly occur in this area. It is also a breeding area for black grouse (Tetrao tetrix) and corn crake (Crex crex).

\section{Part M: Radvanovický hřeben, Stožecká skála, Medvědice (Radvanovický hřeben Mts., Stožec Rocks, Medvědice Mt.)}

Location: Two forested areas located about $1 \mathrm{~km}$ west of České Žleby and $1 \mathrm{~km}$ north of Stožec, in the southern part of the Šmava NP.
Conservation objectives: Montane acidophilous beech forest; herbaceous plant-rich beech woods; black stork; Ural owl.

Natural characteristics: The Radvanovický hřeben, a mountain ridge above $1000 \mathrm{~m}$ a.s.l., is covered by a large complex of species-rich beech forest (as. Dentario enneaphylli-Fagetum) and smaller fragments of montane sycamore- beech forests (as. Aceri-Fagetum). Xerophytic and lucidophilous vegetation (all. Asplenion septentrionalis) with maidenhair spleenwort (Asplenium trichomanes), forked spleenwort (Asplenium septentrionale), silver cinquefoil (Potentilla argentea) and burnet saxifraga (Pimpinella saxifraga) grows on small rocks at Stožecká skála. Invertebrates typical of natural species-rich beech forests occur in this area. For example, Pterostichus selmanni roubalii Schauberger, subspecies of carabid that was described from the Bohemian Forest, Otiorhynchus labilis, Oreina cacaliae and Perizoma taeniata regularly occur in this area. Malacofauna of this area is specific and species rich and this is also an important breeding area of the black stork (Ciconia nigra), stock pigeon (Columba oenas), Ural owl (Strix uralensis), black woodpecker (Dryocopus martius), white-backed woodpecker (Dendrocopos leucotos), and red-breasted flycatcher (Ficedula parva).

\section{Part N: VItavský luh včetně Malé Nivy (VItavský luh floodplain wetlands and Malá Niva peat bogs complex)}

Location: River floodplain in a flat valley of the Upper Vltava River in the southeastern part of the Šumava NP.

Conservation objectives: Complex of peat bogs and floodlain wetlands (moors, transition mires, fens, peat and waterlogged spruce forests, pinus bog forests, birch mire forests, reed and tall-sedge beds, abondened river arms, alder stands, willows); natural succession; alluvial wet meadows; phenomen of unique river basin with natural dynamics; black grouse; corncrake; pearl mussel; otter; Carabus menetriesi.

Natural characteristics: The area includes the floodplain of the Upper Vltava River, where the river meanders freely at the bottom of the old Tertiary valley. The relatively wide floodplain (about $1000 \mathrm{~m}$ ) is regularly, especially in the spring, flooded and the river changes its trajectory dynamically. There are numerous abondoned river arms. Described geomorphological type of water flow and wide alluvium is more typical of lower altitudes and its existence in mountain conditions is unique.

Nutritionally poor geology in combination with less permeable layers of fine river sediments supports peat deposition, which is crucial for a high proportion of oligotrophic marshlands and peat bogs in the area. Different habitat conditions and natural river dynamics define complex horizontal structures and vegetation diversity. The river floodplain are generally characterized by steep environmental gradients (moisture, trophic, disturbance) 
reflecting rugged micro-relief. In the Upper Vltava River valley, natural dynamics of the vegetation resulting from the changes in the course of the river across the floodplains is also significantly influenced by human activities.

Many parts were previously deforested and used for agriculture. Since the middle of 20th century, however, most of the fields and meadows were abandoned and the vegetation is changing due to natural succession. Ombrotrophic raised bog mires of valley type are an important part of the Vltava river alluvium. Most of them are now fully covered by Pinus rotundata bog forests (all. Sphagnion magellanici, as. Vaccinio uliginosi-Pinetum mugo) occasionally accompanied by marsh Labrador tea (Ledum palustre, as. Ledo palustris-Pinetum uncinatae). There are also sites with a high proportion of natural forest-free peat lands with typical vegetation (all. Sphagnion magellanici, Oxycocco microcarpi-Empetrion hermaphroditi and Sphagnion cuspidate). Shallow water and oligotrophic oxbow pools offer suitable conditions for preservation of some relict phytocenosis such are communities with rare yellow pond-lily (Nuphar pumila; all. Nymphaeion albae, as. $\mathrm{Nu}$ pharetum pumilae). Communities with alpine pondweed (Potamogeton alpinus; as. Potametum tenuifolii) also occur rarely here. Submerged phytocenosis of some bladderworts (all. Utricularion vulgaris, as. Utricularietum australis) are relatively abundant but communities with Sparganium minimum and Utricularia ochroleuca (all. Sphagno-Utricularion) are very rare. The ecology of naturally sedimented and isolated sections of the river is very unique.

Also the fauna of this area is very important. One of the last viable Central European populations of pearl mussels (Margaritifera margaritifera) lives in this area. Different rare and relict invertebrates occur here: for example the earthworm Lumbricus baicalensis; spiders Arctosa arctigena lamperti, Pardosa hyperborea, Gnaphosa microps and Dictyna major; dragonflies Somatochlora arctica and Aeschna subarctica; butterflies Boloria aquilonaris, Proclossiana eunomia, Coenonympha tullia and Vacciniina optilete; boremontana species of Diptera. The Upper Vltava River valley is an important breeding area for black grouse (Tetrao tetrix). Diversity local ornithofauna is rich and the northern birch mouse (Sicista betulina) is abundant.

\section{Part 0: Trojmezná - Smrčina (A mountain range between Trojmezná Mt. and Smrčina Mt.)}

Location: This area is located in the most southern part of the Šumava NP, along the state border CZ-Germany and CZ-Austria. The area has a marked altitude gradient and is longer than $19 \mathrm{~km}$ but not very wide, usually only about $2 \mathrm{~km}$.

Conservation objectives: Athyrium distentifolium rich spruce forests, acidophilous montane beech forests, herbaceous plant-rich beech woodlands, glacial lakes and corries, backwalls and rock fields; Isoëtes echinospora, capercaillie, three-toed woodpecker, lynx; old-growth forests.
Natural characteristics: The central part of the border range, which is above $1300 \mathrm{~m}$ a.s.l., includes the peaks: Špičák, Tř́stoličník, Vysoký hřeben, Trojmezná, Trojmezí, Plechý, Studničná, Hraničník and Smrčina. This zone includes the glacial lake Plešné jezero with a big glacial cirque, high rocky walls and moraine. The highest ridge of the mountain zone is dominated by spruce forests (as. Calamagrostio villosae-Piceetum) and the steeper slopes and rocky habitats are covered by Athyrium distentifolium - rich spruce forests. Dryopterido dilatata rich spruce forests (Dryopterido dilatatae-Piceetum) grow in some nutritionally poor debris. At lower altitudes are dominated by acidophilous montane beech forests and herbaceous plant-rich beech woodlands. Old, natural and valuable stands of primeval forests as well as young mixed forests with a natural structure and species composition are common in this area. Just at the border, there is a smaller wetland complex (Rakouská louka) with a fragment of raised bogs, which is surrounded by waterlogged spruce forests. Deer grass (Trichophorum cespitosum), crowberry (Empetrum nigrum), bog rosemary (Andromeda polifolia), cranberry (Oxycoccus palustris), few flower sedge (C. pauciflora), and bog sedge (C. paupercula) grow here. Primary grassland communities (all. Calamagrostion villosae and Dryopterido filicis-maris-Athyrion distentifoli) with Gentiana pannonica occur in the glacial cirque of the Plešné jezero lake. Debris fields and rocky areasare colonized by dwarf pines (Pinus mugo) or the very rare hybrid Pinus $\times$ celakovskiorum. The bottom of the Plešné jezero lake is the only locality for Isoëtes echinospora in the Czech Republic. Communities with bottle sedge (Carex rostrata) covering the Plešné jezero lake banks are habitats for other rare species (i.e., Dactylorhiza fuchsia; Pedicularis sylvatica, Platanthera chlorantha, Willemetia stipitata, and Carex pulicaris).

Relict invertebrates are represented for example by the spider Hahnia montana, longhorn beetle Tragosoma depsaria, leaf beetle Chrysomela lapponica, and beetle Otiorhynchus proximus. Unique water species Glaenocorisa propinqua and Heterocope saliens live in the glacial lake. Capercaillie (Tetrao urogallus), three-toed woodpecker (Picoides tridactylus), ouzel (Turdus torquatus), Tengmalm's owl (Aegolius funereus) and peregrine (Falco peregrinus) regularly breed in this area. The area is also an important part of the home range of several lynx $(\operatorname{Lyn} x \operatorname{lyn} x)$.

\section{Conclusions}

Since its establishment the zonation of the Šumava NP has undergone significant changes and currently and for many years has been evaluated as unsatisfactory. Several new zoning arrangements have been proposed over the last couple years, all of which indicate that the most valuable parts of the area (i.e. the core zone or Zone I of the Sumava NP) are still in the same locations. Natural con- 
ditions, habitat qualities and occurrence of rare species are stable or only changing slightly in time. But the key question is how a new zonation proposal will respect the need to have zones of sufficient size. Whether or not only the sites of great conservation interest are protected (e.g. only the moors without the surrounding waterlogged forests or only fragments of old growth forests without the surrounding close to nature forests) or also the area immediately surrounding and adjoining these sites is important. If not, we are left with a very fragmented zonation, which could be called "pearls archipelago". The most valuable parts of the area, the so-called pearls, are strongly threatened, especially if intensive or inappropriate management practices are applied in their surroundings (e.g. clear-cutting of spruce stands affected by bark beetle or changes in water regime due to construction of new roads or extensive maintenance of old ones). But there is also another possibility. The natural islands of highest value can be connected to bigger units by bio-corridors or transition zones with natural or close to natural habitats large enough to be effective. The careful evaluation of the quality and overall potential of the area (zone) is essential. If the species compositions of these areas, status of key components of the ecosystem and the protected phenomena occurrence are in natural or a close to natural state, it is desirable to allow spontaneous development and avoid human intervention.

We can assume that the quality of the natural conditions and potential for natural development in the Šumava NP are high. There is a unique opportunity to change a currently unsatisfactory zoning and use it as an effective tool for protecting the Šumava NP. This paper presents mainly biological arguments, but social and political aspects are also very important and need to be addressed during the negotiation process. A consensus of the opinions of the public, politicians, local representatives, protected area managers, biologists and NGOs is necessary for safe guarding the future of the Šumava NP.

\section{Acknowledgements}

The authors wish to thank many scientists, researchers, conservationists from different academic institutions, universities, professional NGOs, and the Šumava NP Administration for their help with the new Šumava $\mathrm{NP}$ zonation preparation and their infinite patience and enthusiasm during many years of the new zonation negotiation. We thank also very much prof. A. Dixon for revising the language and two referees for their valuable comments.

\section{REFERENCES}

Brunner R (1996) Parks for Life: Transboundary Protected Areas in Europe. Final Report, IUCN (IUCN/WCPA Parks for Life Coordination Office), Ljubljana, Slovenia.

Dudley N (ed) (2008) Guidelines for Applying Protected Area Management Categories. Gland, Switzerland: IUCN.

Kiener H, Husslein M, Engmaier KH (eds) (2008) Natura 2000. Management im Nationalpark Bayerischer Wald. Grafenau.

Křenová Z, Kiener H (2011) Europe’s Wild Heart - Responsibility for Europe. In: Vasilijevic M, Pezold T (eds) Crossing Borders for Nature. European examples of transboundary conservation. IUCN, pp 42-45.

Meyer T, Kiener H, Křenová Z (2009) Wild Heart of Europe. Int J Wilderness. 15: 33-40.

Šolar M (2009) New wilderness model in European Concept. In: Husslein M, Kiener H, Křenová Z, Šolar M (eds). The appropriateness of non-intervention management for protected areas and Natura 2000 sites. Srni Conference Report. Grafenau/Vimperk 2009, pp 16-17. 